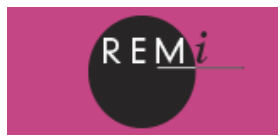

Revue européenne des migrations internationales

vol. 21 - n³ | 2005

Familles, destins personnels et appartenances

collectives en migration

\title{
Migrants to Citizens
}

Bangladeshi Women in Tower Hamlets, London

\section{Kate Gavron}

\section{(2) OpenEdition}

\section{Journals}

Electronic version

URL: https://journals.openedition.org/remi/2515

DOI: 10.4000/remi.2515

ISSN: $1777-5418$

Publisher

Université de Poitiers

Printed version

Date of publication: 1 December 2005

Number of pages: 69-81

ISBN: 2-911627-45-8

ISSN: 0765-0752

Electronic reference

Kate Gavron, "Migrants to Citizens", Revue européenne des migrations internationales [Online], vol. 21 -

n³ | 2005, Online since 01 December 2008, connection on 15 April 2022. URL: http://

journals.openedition.org/remi/2515 ; DOI: https://doi.org/10.4000/remi.2515

This text was automatically generated on 15 April 2022.

() Université de Poitiers 


\title{
Migrants to Citizens
}

\author{
Bangladeshi Women in Tower Hamlets, London
}

\author{
Kate Gavron
}

1 The "East End" of London is one of the most studied parts of the United Kingdom. The research discussed here took place in the 1990s in the present borough of Tower Hamlets, which was formed from the three old boroughs of Bethnal Green, Stepney and Poplar, three of the "hamlets" just beyond the walls of the old City of London and near the "Tower" of London. From the nineteenth century, novelists (Morrison, 1896), social reformers (Booth, 1902) and, later, sociologists and commentators (for example Banton, 1955 ; Samuel, 1981; Cornwell, 1984), have used the East End as their laboratory, to examine the social and economic activity of this part of the capital city, at one time the largest working-class urban enclave in the world, and for centuries the point of arrival (Bermant, 1975) and settlement of numerous immigrants.

2 The most significant immigrant communities to settle in this part of London over the past four centuries were the French Huguenots refugees, then Irish labour migrants, later, in the late nineteenth century, Jews from Russia and eastern Europe and, most recently, Bangladeshis from Sylhet, in the north-east of the country. The best-known studies of the area are probably those carried out by Michael Young and Peter Willmott in the 1950s (Young \& Willmott, 1957, 1973; Willmott, 1966) and by the social historian of the nineteenth-century East End, William Fishman $(1981,1988)$.

\section{Methodology}

3 I was fortunate in being able to work with Michael Young in the 1990s, at the Institute of Community Studies, on a restudy (Dench, Gavron \& Young, 2006) of his famous book, Family and Kinship in East London (1957). A principal source of data for the restudy and for my own research was a survey of 799 residents of the old borough of Bethnal Green, selected at random from the electoral register. The survey was carried out in 1992 and initial data analysed by BJM Ltd. Information about contact with members of respondents' families was gathered for 2565 people living within the 799 households, and for a total of 8370 people including those living outside the respondents' 
households. Of the original informants, 171 , or $21,4 \%$, were Bangladeshis and they provided information on a further 853 people living in their households and another 925 relatives living elsewhere, of whom 486, or 53\%, were living in Bangladesh. This gave us information on some 1949 Bangladeshis and provided a very rich dataset with useful information about the population, including family size and contact with relatives, both in Bangladesh and in the UK.

In addition, further more intensive and less formal interviews were carried out with approximately 100 respondents, and I personally carried out over one hundred hours of informal interviewing with young Bangladeshi women, subsequently transcribed and analysed. In addition, I spent a considerable amount of time over some three years with Bangladeshi families and with young Bangladeshi women at school and at home. My principal sources of information for what follows are my own interviews, backed up with data from the BJM survey and other official data sets, including the 1991 and 2001 national censuses.

\section{Migrants and citizens}

5 The title of my PhD thesis was "Migrants to Citizens". By using this title I indicated an important difference between first and second generation members of the British Bangladeshi community living in Tower Hamlets. The "migrants" were the first generation, the parents in most households, who were oriented towards their homeland of Sylhet, the district in northeastern Bangladesh from which a large majority of British Bangladeshis originated. As with other minority communities in Britain (Anwar, 1979; Shaw, 1988), the men came originally as temporary migrants, expecting to live in Britain for only a few years before returning to Bangladesh, having accumulated money for investment in land and other property.

6 For various reasons, including the increasingly restrictive immigration legislation passed by successive British governments (Gordon \& Klug, 1985), they eventually decided instead to settle in Britain permanently, or at least until the end of their working lives. The wives and children of these men joined them in Britain many years after their first arrival, in many cases twenty years later. To emphasise the difference between men and women's experiences, our own data showed that the peak period for the arrival of men was 1960 to 1965 , and for women and their children from 1980 to 1985 , based on the dates of arrival of over 1,000 British Bangladeshis.

7 Many of the first generation of male migrants have now retired in Sylhet, to enjoy the land they acquired and new houses they built during their years in Britain, throughout which they continued to send substantial remittances to their family in what they considered "home" (Gardner 1995). Some male migrants left their wives in London living in the households of their sons. In these cases, a few of these men have other wives who have remained permanently in Bangladesh and who will be responsible for the care of their husbands in the last years of their lives, while their second wives stay in London looking after grandchildren in their children's homes.

8 The original migrants' children are the "citizens" of the title, born or at least educated in Britain, and oriented almost entirely towards Britain and a future as British citizens. They are mere visitors to Bangladesh, if they go there at all. Like other British visitors to Bangladesh, many of them find the country to be a difficult and uncomfortable 
environment in which to live, despite the welcome and affection they receive from relatives still living in rural Sylhet. The second generation know about their relatives in Bangladesh but they have seen little of them during their lives, and they feel less financial responsibility, or emotional commitment, towards them than their parents do.

9 It is this second generation, the "citizens", that I concentrated on in my research, looking at the girls and young women who had been at least partly educated in Britain. What I wanted to find out was what aspirations they had for their future, what strategies were open to them to use in achieving their ambitions, and what constraints there were, cultural, religious or otherwise, that might inhibit or prevent them fulfilling their ambitions.

10 I was therefore interested in the question of how women from recent immigrant backgrounds cope in a new social and cultural environment. Some of what I found in London is replicated in other parts of the UK, other factors are specific to this particular part of London. Where relevant I will try to make clear which are local factors and which would be generally applicable to other Bangladeshi communities, or indeed to other Muslim communities from the Indian sub-continent in Britain.

\section{Bangladeshis in Tower Hamlets}

11 Census information shows that the population of the borough of Tower Hamlets in 2001 was just over 196000 people, a 17\% increase since 1991. This was the third largest population increase of any borough in Britain, due partly to inward movement by middle-class residents as a result of property development, but due principally to an unusually high birth rate in the borough. The borough has a much younger age profile than for the UK as a whole, with a significant bulge in the population aged 20-35, with fewer than average people in all ages over 40 and higher than average numbers in all ages below 20. This is principally because of Tower Hamlet's Bangladeshi population, some 66000 people, or $33 \%$ of the population. This is the largest number of Muslims in any one borough in the whole of Britain, and this Bangladeshi population is considerably younger in profile than the rest of the country, both because the wives and children are relatively recently arrived immigrants compared with other groups, and because the Bangladeshi community has a high birth rate.

All Muslim communities originating in the Indian sub-continent and now living in Britain have some things in common: a preference for marriage within their own group; occupational specialisation, depending on their residential location in the country; poor average educational achievement compared with some other immigrant communities; and high levels of religious observance. Finally, increasingly in recent years and in particular since September 2001 and the events in London in the summer of 2005, they suffer from the suspicion and hostility of members of other communities in Britain.

13 When looking at young Bangladeshi women's situation in Britain and how they interact with the wider society, different Muslim communities have much in common. However, in Tower Hamlets there are two local factors which are unique to this part of the UK and which impinge on the capacity of women to affect their own life courses: the neighbouring City of London and the particular local history of immigration. 


\section{The City of London} centre of Britain and arguably of Europe. The consequence of this is that there is a highly active local economic environment, with flourishing service and leisure industries. This is in stark contrast to most of the other cities in Britain containing large Muslim communities. But there is also a parallel history of particular economic activities, niche occupations if you like, which have grown up in this part of London. For centuries the most lucrative source of work were the London docks, the arrival point for people and for goods of all kinds; animal, vegetable and mineral (Hill, 1977). However, for new immigrants there have also been specific employment areas for different groups, and the Bangladeshis are a good example of this. The two principal local occupations for Bangladeshi men are in clothing manufacture and restaurants. Work in clothing manufacture, especially leather clothing, is the remnant of a centuries-old occupation in this part of London, ever since leather tanners were expelled from the City in the medieval period, along with various other "polluting", noisy and dirty trades which were removed from the growing centre of financial activity (Palmer 1989).

Bangladeshi men tend to work in small clothing factories, much of this being the specialist machining of leather jackets, coats and other items of clothing. Many of these factories were managed by Jewish owners when Bangladeshis first became active in this economic niche, and some are still owned by non-Bangladeshi businessmen, but more and more Bangladeshis are themselves taking over existing businesses and starting new ones. From being employees when they first arrived in the area, more and more of them are now employing others, including newly arrived fellow Bangladeshis. The level of employment in clothing manufacture has, however, diminished somewhat in recent years because of the growing export of this work to developing countries throughout the world. There is an expanding clothing sector in the economy of Bangladesh itself, partly facilitated by Bangladeshis who lived in London, worked in clothing manufacture, and then returned to Bangladesh themselves and started new businesses in rival to those in London, with considerably cheaper labour costs. The result is that there is more reliance on the second employment sector.

The second main male Bangladeshi occupation is work in Indian restaurants. Almost all "Indian" restaurants in Britain are in fact run by Bangladeshis, and one of the largest concentrations of Indian restaurants is in and around Brick Lane, a street in the west of Tower Hamlets. Brick Lane itself is the heart of the local Bangladeshi community, so much so that part of Brick Lane and a few surrounding streets have been renamed "Banglatown". It is within walking distance of people working in the City itself, and it is easily accessible for the middle-class residents of docklands and the more salubrious areas of the east end of London. Catering work also has a long history, ever since the first Bengali-run cafes were opened in the nineteenth century to cater for the seamen from Sylhet, who were on temporary leave in London while awaiting their next voyage back to Calcutta, their port of embarkation in India. When the greatest number of Bangladeshi migrants arrived in the 1960s, many of them found work in the kitchens of the large London hotels. Some still work in hotels; furthermore, this is work that in some cases has been passed from father to son.

Revue européenne des migrations internationales, vol. $21-n^{\circ} 3$ | 2005 

in this part of London, while the adjacent City of London has given employment to those in younger generations with higher level educational qualifications.

\section{Local history: immigrants and competition for resources}

Tower Hamlets is an area long associated both with immigration and with xenophobia For centuries, migrants and refugees have arrived in the London docks seeking work and housing in a new country, and many have been met with hostility and resentment from the local population, overwhelmingly made up itself of the descendants of previous immigrants. For example, Huguenot refugees from France settled in the Brick Lane area of London in the late seventeenth century, escaping persecution in France after the revocation of the Edict of Nantes, and Irish migrants arrived throughout the eighteenth and nineteenth centuries to do construction work in and around London. Later, Jews arrived from Russia and the countries of eastern Europe, especially in the late nineteenth and early twentieth centuries but also in the 1930s. This concentration in one small district of London was partly because of the proximity of the nearby London docks, the point of arrival for shipping, but it was also because of the longstanding local informal economy and the cheap living costs associated with it. Immigrants could find cheap but overcrowded housing and ill-paid, insecure work, scratching a living on the edges of the prosperous centre.

There has been a long parallel history of hostility to the latest new arrivals throughout the centuries, as the poor of east London fought and competed for accommodation and work (Husbands, 1982). In the first part of the twentieth century this part of east London was a successful recruiting ground for the British Union of Fascists and to this day the local white population remains a recruitment target for neo-fascist political parties. The extreme right-wing has had little success in local elections recently, but they are a continuing threat to good community relations throughout east London. The area has supported the Labour Party consistently in the past, despite occasional larger votes for the right-wing extremists, but in 2005 one of the local Labour Party MPs lost her seat to an independent candidate who had taken a prominent role in the movement opposed to the war in Iraq. His success was undoubtedly due mainly to the growing political activism and interest of the Bangladeshi voters.

These two aspects of local history, immigration and hostility, have important effects on young Muslim women's lives. I now turn to three ways in which the particular local circumstances and environment influence young Bangladeshi women's ability to fulfil their aspirations: firstly, the nature of the employment found in and near the City of London and, secondly, local Bangladeshi employment practices and how they affect men and women. Finally, I will consider arranged marriage as practiced by Bangladeshis, and the advantages and disadvantages for women of marrying men from Bangladesh.

Revue européenne des migrations internationales, vol. $21-n^{\circ} 3$ | 2005 


\section{Work in the City of London}

21 In recent years girls in Tower Hamlets have outperformed boys at school in the achievement of educational qualifications. There are several reasons for this and girls' greater educational achievement is a phenomenon seen in most communities and in most places. Historically, educational achievement has been very low in Tower Hamlets but more recently there has been a steady and impressive improvement by both girls and boys, and the Bangladeshi school students are in the vanguard of this success. Bangladeshi school pupils outperform their white counterparts, girls doing slightly better than boys in both ethnic groups. In fact, Tower Hamlets' 2002 GCSE results (the examinations usually taken at age 16) made it the "fastest improving" borough in the UK, albeit from a low base, and since 1990 the number of school pupils entering higher education in any one year has increased by more than $200 \%$, despite the fact that $64 \%$ of the borough's school students have a home language other than English.

This is an impressive record and a good demonstration of the longstanding history of enterprise and industry within immigrant communities. It also means that the young people of Tower Hamlets are beginning to provide a better qualified locally-based workforce for the adjacent financial centre. The majority of jobs in financial services in the City of London that have been created in recent decades have been for highly qualified executives, lawyers and accountants. However, there have also been a lot of jobs for well-educated graduates and non-graduates, especially doing secretarial and clerical work, of the sort customarily thought of as better suited to women than to men. Also, there are many new jobs in businesses servicing city workers, for example work in shops, pubs, restaurants, health clubs and the provision of other leisure activities. Work in these parts of the service sector is commonly done by men as well as women.

In addition to the work in the City, much of it more easily accessible to Bangladeshi women than men, many women also work in local public sector jobs, for the local administrative authority, the educational authority and the health authority. Indeed, because of the dominance of the state sector in local employment within Tower Hamlets itself, there is a predominance of "women's" jobs in the borough, following the closure of much of east London's manufacturing businesses. The London docks finally closed in the 1970s, as bulk shipping moved to vast container docks further east, and almost all of the associated businesses closed at the same time as the docks or shortly afterwards.

Much of the work that the first Bangladeshi male migrants did simply does not exist any longer in east London, and many of the original migrants have been unemployed and living on state benefits for years, during the time that their literate and educated daughters were finding work for the first time. This is so much the case that during research I came across a number of large Bangladeshi households in which a young woman was the only household member with a full time job in the formal economy, although some of her younger male relatives may have had work of some kind, working for cash in the informal economy. Despite the access to work, the Bangladeshi community is still the poorest of the main minority ethnic groups in Britain (Berthoud, 1998). 


\section{Men's work, women's work: Bangladeshi patterns of employment}

As already mentioned, the main local employment sectors managed by Bangladeshis themselves are restaurants and small clothing factories. In restaurants all employees are male, in clothing factories almost all employees are male, although many first generation Bangladeshi women are home-workers making, for example, coat linings for the local leather factories, paid at piece-work rates. On top of this, the local Bangladeshi food shops and groceries are staffed by men, as are almost all of the other Bangladeshi-owned businesses. All this means that women tend to look outside the Bangladeshi community for their work. This also means that they are more likely to look outside their immediate local area, although, as has been mentioned, many do work for the borough authority and in local schools.

Furthermore, male Bangladeshis are more likely to work in Bengali-speaking environments, whether in small clothing factories or in the kitchens of restaurants, just as the first generation of Bangladeshi men frequently worked together on night shifts in textile factories in the north of England. One effect of this early employment practice was to reinforce the tendency of the original Bangladeshi migrants to live and work in a somewhat "encapsulated" situation, without needing to learn English to a level which would enable to them to branch out into a wider range of occupations (Eade, Vamplew \& Peach, 1996). In this respect they were different from the Englishspeaking Caribbean migrants who arrived at the same time in the UK but who worked from the beginning in the kinds of public service jobs that brought them into contact with the wider British society, principally employed in public transport and the health service.

The result of the early work experiences of Bangladeshi migrants and their adaptation to the changing employment situation in the UK has tended to keep older men in exclusively Bangladeshi environments. When they were first in the UK, Bangladeshi men not only worked in the Bengali-speaking nightshifts but also lived together in entirely Bengali-speaking lodging houses, cooking and eating together. Many of the men who have been in Britain for several decades continue to have a poor level of English, many of their wives still speak little or no English, and children whose parents have been in Britain for many years are still arriving in school with almost no English. In addition, the small number of new husbands and wives still arriving from Bangladesh will usually speak little or, in the case of most wives, no English. For many, therefore, education in English to a high level is realistically only available at school, and therefore only to those Bangladeshis who are born in the UK or who arrive as children.

\section{Racism and gender}

Racism and xenophobia, shown in hostile attitudes and aggressive behaviour, have consistently been associated with this part of London, because it has long been the meeting point for arriving migrants and refugees and a poor local population. Hostility has necessitated the Bangladeshi community, like the Jews before them (Gartner 1960), forming their own local economy and employment sectors. My own informants suggest 
that the day-to-day effects of racism are experienced rather more by men than women in the Bangladeshi community: men and boys are more likely to be physically attacked and, according to anecdotal evidence, men are more likely to believe they have been refused a job for reasons of racial discrimination. Overall we can say that racism has blighted the life of many Bangladeshis in Tower Hamlets, and they feel vulnerable in some parts of the borough. This physical insecurity not only intensifies efforts to find accommodation in or near the "Banglatown" part of Tower Hamlets (Phillips 1986, 1988 and CRE 1979, 1988), but it also directly affects behaviour, including influencing decisions that have to be taken about where to work and what sort of jobs to apply for.

What is being argued here is that the pattern of local Bangladeshi employment favours men' participation, whereas the local public sector and the nearby City of London employment favours women, partly because of their greater educational achievements. Women's employment takes them into mainstream British society more than men. This tendency, largely to do with local employment practices, is also almost certainly reinforced by the wider British society's encouragement for women working outside the home, as opposed to the customary disapproval of women's outside employment in traditional Bangladeshi communities. In Tower Hamlets, therefore, all these factors work together to encourage Bangladeshi women's growing participation in the mainstream employment market.

The consequence of these different factors is that Bangladeshi women who are in paid work are more likely to work in ethnically-mixed environments than men, and the well qualified among them are more likely to work outside Tower Hamlets. This in itself may mean that women have more mainstream and outward-directed career trajectories. This will almost inevitably have an effect on the attitudes of their own children, perhaps especially their daughters.

31 It should be noted here that this is somewhat different in Bangladeshi communities living in other parts of Britain. This part of London is unique in the diversity of employment opportunities available, and there is a very different employment environment in the northern cities, historically dominated by textile manufacturing and heavy industries. Furthermore, the smaller size of Bangladeshi communities living in other towns and cities means that there are fewer specifically Bangladeshi businesses able to offer work to members of their own community, most notably to the recently arrived immigrants, almost invariably the husbands and wives of British Bangladeshis, who have yet to perfect their English.

\section{Marriage partners: choices in arranged and "love" marriages}

32 As immigration legislation has effectively stopped all primary immigration, virtually the only way of getting permission to migrate to Britain is as the husband or wife of a British citizen. This means that the choice of marriage partner can be fraught, with considerable pressure from relatives in Sylhet being put on parents living in Britain to agree that their children should marry young people raised in Bangladesh. The pressure may come from friends, acquaintances and business contacts as well as from relatives. Most marriages are arranged to some extent, but the younger generation is increasingly involved in the choice of partner and more parents are agreeing to "love" marriages (Gavron 1996). Conceding to "love" marriages does not extend, however, to 
easy acceptance of partners outside the Bangladeshi, or at least Muslim, community, and the number of marriages between Bangladeshis and non-Bangladeshis remains statistically so small as to appear as almost non-existent in census figures.

Among young Bangladeshi women there is a lot of discussion about marriage, about living arrangements following marriage and about the advantages and disadvantages of different marriage choices. There are several factors which are important in the context of this paper's concerns. Firstly, women educated in Britain are pretty unanimous that they do not want to marry too young:

“For [my cousin aged 18] marriage isn't the end of the world but for me it is; I'd hate the idea of marriage. I don't want to get married too young. I've got nothing against it later on, but getting married at 18 , for me that will be the end of the world. Because once you are married you have other responsibilities." [Girl aged 17]

If young women are ambitious, academically successful and have specific ideas about their future working careers, they may prefer to marry men from Bangladesh. This may seem surprising at first sight, and it is certainly not a universal preference, but there are several reasons why they may make this choice. Firstly, because they will not have to live with their husband's parents who will be living in Bangladesh. As one girl said, "If you get somebody from Bangladesh, there won't be much problem, because your inlaws will be in Bangladesh." Secondly, in these circumstances their husbands are unlikely to get good jobs themselves, so that the wives will be the main household earners.

Traditional practice is that married couples live in the households of the husband's parents and younger wives operate to a greater or lesser extent under the authority of their mothers-in-law. This pattern is still surprisingly common in Tower Hamlets, despite the small number of homes large enough to accommodate joint family households. A new wife will often live with her husband, his parents and his unmarried siblings, at least until his younger brother has married and space becomes too cramped to accommodate yet another couple. If a new well-educated wife goes to live with her husband's parents, they are not always trusted to adhere to promises made before the marriage, as in this example:

“The thing is you don't know for sure, because they could be putting on an act. Like my sister's mother-in-law did. She was like an angel when she came over to us... Mum was asking [my sister's] mother-in-law, 'Are you going to let my daughter study?' And she said yes. As soon as she got married afterwards, it was, 'No, we can't let our daughter-in-law go to work, or even go to study'. As soon as after a few months. So you can't trust them as well." [Girl aged 18]

The acute housing shortage in this part of London also means that until a young couple have children, they are unlikely to be able to access local public sector housing. If a woman marries a man whose parents still live in Bangladesh, she has more chance of living either with her own parents or as an independent couple. In practice, it is usual for these women to live with their parents only until their husbands have joined them in London, by which time they may also have a first child and access to their own housing.

In order to get permission to be joined by a husband from Bangladesh, commitments must be made to the immigration authorities that the new immigrant can be adequately housed and that work is available. In order to satisfy this requirement, jobs are promised in restaurants, at low rates of pay and in a fairly unregulated part of the economy. Theoretically at least and often in practice, therefore, Bangladeshi women 
married to newly arriving immigrant men will have a more powerful position within their own household, because of their superior earning ability, their command of English and their knowledge of British customs and culture.

Another option, open to growing numbers of young women, is to choose their own partner without their parents being involved. If they have a "love" marriage they can make sure they choose a Bangladeshi man whose ideas about women's role, domestically and in the outside world, coincide with theirs. This can apply whether their husbands have been educated in the UK or in Bangladesh, as one of my informants explained, in this case about her own future husband:

"I did say things like how he has to help me out with the cooking and how it has to be a two-way thing. Because when he comes over here [from Bangladesh], he's not going to be earning a great salary, is he? So I have to make it quite clear that we both work together. I said marriage is a two-way thing and people have to compromise when it comes to it. It can't be strict women's jobs/men's jobs. If people have these fixed ideas, I don't think any marriage would ever work. When situations changes, you have to change along with it."

39 I have referred earlier to the better educational achievements of girls. While this is generally the case in the population as whole, I believe that it is a crucial and conscious part of the strategy of self-determination among Bangladeshi girls, not least by enabling them to delay marriage for a few years. It is compulsory to attend school in Britain until the age of 16 , but if girls stay at school after the age of 16 to do A levels, which are generally taken at 18 , and even more so if they do a university degree, they will be relieved of pressure from parents to agree to a marriage, whether arranged or not. This pressure can be intense:

"Community pressure, peer pressure, relatives back at home, pressure from them really. [But] I don't think parents are going to force us so much. I think really it's making them proud that we are doing so much. So I think they are going to lay back really. Before, it was once you turned 16 you got married, then it was once you turned 18. So it's like moving on." [Girl aged 18]

Many of my informants have confirmed that delaying marriage and having a greater say in the choice of their marriage partner has been a powerful motivating factor in their school performance:

"I think what makes us work hard is the fear of getting married at a young age. And also, this is what parents usually say to their daughters, they say 'Well, if you don't do well in your exams, you're going to get married.' So that makes you work! That makes you work!" [Girl aged 17]

41 And also it is one of the reasons why they want to continue in university education after school:

"Last week [my sister] was speaking to my dad: 'Can I finish my MSc first?' and my dad said 'Impossible!' She went all red, and she was looking at my brother for support, and my brother just went, 'I can't do anything!' They chucked us [her younger siblings] out because they wouldn't discuss it in front of us, and I wanted to know what they were saying. And she sort of gave my dad a hint that when she does her MSc we could get married! I was like sitting there, thinking 'the older one should get married first!' I don't want to get married before her, I want to have a brother-in-law [first]." [Girl aged 18]

42 As far as the attitudes of the men chosen either by their parents or themselves is concerned, some young women say that men educated and living in London have more traditional and conservative views than educated men from Bangladesh, but some say the reverse. When this is examined more closely, there seems to be little doubt that, on 
the whole, higher educational qualifications tend to go together with more progressive views about women's rights, whether the education has taken place in Britain or in Bangladesh. Having said that, there is the current concern about growing interest in the more politically extreme versions of Islam among young Muslims at British universities, and this may well be affecting male graduates' attitudes to women's roles inside and outside the home, as well as their attitudes to Britain and the west generally.

This is no doubt affected by international as well as national politics, and might exacerbate gender relations in the Bangladeshi community, especially if women's career paths continue to move in a more mainstream trajectory than men's and if young Asian men continue to be over-represented among the unemployed, imprisoned and otherwise disadvantaged. What we can speculate from women's growing activity in mainstream employment is that marriage with men outside the Bangladeshi community is likely to increase gradually, especially for the most highly qualified women. Also, that young women will increasingly be involved in the choice of their marriage partners, not least because their parents can see that divorce and separation rates are growing among Bangladeshis, and in particular between couples in which one partner has grown up in Britain and the other in Bangladesh.

\section{Conclusions}

Parents nowadays acknowledge that their British-educated daughters have expectations of marriage which may not be satisfied by strategic alliances with friends or kin from Sylhet. Women are increasingly liberated to take responsibility for the course of their own lives, whether it is in the choice of a career or a partner. The special circumstances of Tower Hamlets may be accelerating a process by which the women in a traditionally conservative community are encouraged to adopt a more typically mainstream lifestyle. This encouragement comes from cultural influences in British society which promote the active participation of women in higher education and the employment market. It also arises from the effects of the local employment market, which excludes women from most Bangladeshi owned or managed businesses, making them seek work beyond their own community.

Finally, it is too early to know how radical versions of Islam will affect day-to-day life for the vast majority of British Muslims who are not part of extremist groups. At the time of writing (September 2005) British Bangladeshis have not been implicated in British terrorist incidents, but it would be naïve to think that young Bangladeshis, especially young men, have not been exposed to the words and influence of Muslim political extremists. However, if one can speculate about the possible influence of conservative influences on young Bangladeshi women, if their potential marriage partners in their own community are unable to agree about women's participation in employment, more Bangladeshi women may find their partners outside their own community. 


\section{BIBLIOGRAPHY}

ANWAR Mohammad (1979) The myth of return, London, Heinemann.

BANTON Michael (1955) The Coloured Quarter, London, Jonathan Cape.

BERMANT Chaim (1975) Point of arrival, London, Eyre Methuen.

BERTHOUD Richard (1998) Incomes of ethnic minorities, Colchester, University of Essex: Institute for Social and Economic Research.

BOOTH Charles (1902) Life and Labour of the People in London (17 Vols), London, Macmillan CORNWELL Jocelyn (1984) Hard-earned lives, London, Tavistock.

CRE (1979) Brick Lane and beyond: an inquiry into racial strife and violence in Tower Hamlets, London, Commission for Racial Equality.

CRE (1988) Homelessness and discrimination: report of a formal investigation by the CRE into the allocation of housing by the London Borough of Tower Hamlets, London, Commission for Racial Equality.

DENCH, GAVRON \& YOUNG (2006) The New East End: kinship, race and conflict, London, Profile Books.

EADE John, VAMPLEW Clive \& PEACH Ceri (1996) "The Bangladeshis: the encapsulated community", in Peach, Ceri, (ed), Ethnicity in the 1991 Census, Vol. 2, The Ethnic Minority populations of Great Britain, London, HMSO.

FISHMAN William (1981) The Streets of East London, London, Duckworth.

FISHMAN William (1988) East End 1888, London, Duckworth.

GARDNER Katy (1995) Global Migrants, Local Lives: Travel and transformation in rural Bangladesh, Oxford, Clarendon Press.

GARTNER Lloyd Philip (1960) The Jewish immigrant in England, 1870-1914, London, Allen \& Unwin. GAVRON Kate (1996) “Du mariage arrangé au mariage d'amour”, in Terrain, Numéro 17, "L'amour", September.

GORDON Paul \& KLUG Francesca (1985) British Immigration Control: a brief guide, London, Runnymede Trust.

HILL Stephen (1977) The Dockers: Class and Tradition in London, London, Heinemann Educational Books.

HUSBANDS Christopher (1982) “East End racism, 1900-1980”, London Journal, 8(1).

MORRISON Arthur (1896) The Child of the Jago. London, Methuen.

PALMER Alan (1989) The East End, London, John Murray.

PHILLIPS Deborah (1986) What price equality? A report on the allocation of GLC housing in Tower Hamlets, London, GLC.

PHILLIPS Deborah (1988) "Race and Housing in London's East End: continuity and change" in New Community, 14(3) 
SAMUEL Raphael (1981) East End Underworld: Chapters in the Life of Arthur Harding, London, Routledge

SHAW Alison (1988) A Pakistani Community in Britain, Oxford, Blackwell.

WILLMOTT Peter (1966) Adolescent boys of East London, London, Routledge \& Kegan Paul.

YOUNG Michael and WILLMOTT Peter (1957) Family and kinship in East London, London, Routledge \& Kegan Paul.

YOUNG Michael and WILLMOTT Peter (1973) The Symmetrical Family, London, Routledge \& Kegan Paul.

INDEX

Geographical index: Royaume-Uni

Mots-clés: Bengladeshis, citoyenneté, comportement matrimonial, femmes, genre, mariage, racisme

\section{AUTHOR}

KATE GAVRON

Chercheure, The Young Foundation, London, 18 Victoria Park Square, London, E29PF. 